\title{
Gender Inequality in Access to Formal Social Security Schemes among Members in the Informal Sector in Laikipia East District, Kenya
}

\author{
Gibson K. Muhuhu ${ }^{1}$, Prof. Wokabi Mwangi ${ }^{2}$, Dr. Hadijah Murenga ${ }^{3}$ \\ ${ }^{1}$ P.O. BOX. 51187-00200, Nairobi. \\ ${ }^{2,3}$ Department of Peace, Security and Social Studies Egerton University P.O. Box 536, 20115 Egerton, Kenya. \\ Department of Peace, Security and Social Studies Egerton University P.O. Box 536, 20115 Egerton, Kenya.
}

\begin{abstract}
Access to the social security schemes by the public is important in ensuring the social welfare of individuals both in the formal and the informal sector, thus the motivation to carry out a study on the challenges facing access to the schemes by the members of the informal sector. This is a sociological study on gender inequality in the access to formal security schemes among members of the informal sector in Laikipia East District. This study was motivated by the desire to document the possible challenges faced by members in this sector in accessing formal social security schemes while taking into consideration the gender differences. Social development theory was used to explain the relationship between the variables of the study. Literature review showed that despite the presence of various legislative provisions on social security in Kenya, the level of access to social security among members in the informal sector had not been widely documented. The study adopted a descriptive statistics research design. The unit of analysis were members of the informal sector. Stratified sampling technique was used to sample 200 respondents for the study while purposive sampling technique was used to sample the key respondents. Questionnaires and interview schedules were used as instruments for data collection. Cross-tabulation was done to show the relationship between different variable investigated. This study found that there was low access to social security schemes among the members of the informal sector where female members were found to have less access to the schemes (5.5\%) compared to their male counterparts (7.5\%). Awareness was found to be a major hindrance to the access to social security schemes where female members of the informal sector were found to be less aware of the available schemes (71\%) compared to the male (61\%). Economic factors were also found to hinder access to the schemes and again female members in the informal sector were the hardest hit with $78 \%$ indicating that they were not able to remit the monthly contribution compared to $46 \%$ male who could not remit the contributions. Finally, government policy on the minimum contribution to the schemes was found to affect access to the schemes where most affected population in the informal sector were female (87\%) compared to the male (83\%).
\end{abstract}

Key words: Social Security Schemes, informal sector, formal sector and gender inequalities.

\section{Introduction}

The effects of the global economic shock of the 1970s, exacerbated by rapid globalization and the resultant drive towards more competitive production of goods, saw developed countries adopting labour policies that have made inroads into the social protection gains previously regarded as being integral to the welfare of state [1]. The labour market has become increasingly casual with new job opportunities being offered in terms of a limited, short term contract, often without formal workplace benefits. Outsourcing of jobs further removes the obligation on the effective workplace to provide benefits for the workers. According to the Universal Declaration of Human Rights, United Nations General Assembly, (1948), everyone has the right to a standard of living adequate for the health and well-being of himself and of his family, including food, clothing, housing and medical care and necessary social services, and the right to security in the event of unemployment, sickness, disability, widowhood, old age or other lack of livelihood in circumstances beyond his control. Motherhood and childhood are entitled to special care and assistance. All children, whether born in or out of wedlock, shall enjoy the same social protection. Social security is a basic human right (International Labour Organization [2].

According to the International Labour Organisation (ILO), about 80 per cent of the world's population has no access to formal social security beyond the possibilities presented by informal networks such as family, kinship groups or communities (ILO, 2006). In other words, four out of every five people in the world live in conditions of social insecurity. This proportion is even higher in countries of sub-Saharan Africa where more than 90 per cent of the population is generally not covered under any social security scheme [3]. In Kenya, existing pension schemes are limited to formal sector workers. The ILO estimates that 'about 84 per cent of the labour force is excluded, while many of those who are covered receive benefits that fall short of their basic 
needs. In addition, basic health care remains out of reach for the 56 per cent of Kenyans who live in poverty' [4].

Social security is seen as a means of protecting citizens against loss of income in the event of social risks. It has a direct impact on poverty reduction both in view of how it protects citizens from falling below critical poverty; and how it helps in mitigating and coping with social risks [5]. Socio-economic conditions in developing countries call for an increasing demand for social security. Bailey [6] asserts there is a yawning gap between those who need and those who actually benefit from one kind of social security or the other. Many subSaharan African countries are in a historical process where traditional risk-pooling/social protection institutions such as the extended family are being constantly reformed. Traditional linear life courses are being replaced with non-linear ones. Exposures to social, economic and ecological risks (exacerbated by internal, external, as well as national and global dynamics) get increasingly complicated [7,8,9].

The challenge inherent in the informal economy with regard to the extension or provision of social security lies in its very fragmented and officially invisible nature. Self employed workers are often not registered in any way. Most social security systems have failed to accommodate the needs of the growing numbers of atypical workers [10]. A general challenge with regard to the informal economy is to identify methods of supporting workers to organize themselves and to build institutions that strengthen and protect their rights [11]. Collection of workers' and employers' benefits in formal social security schemes is usually administered through the employer, but in the informal economy this edifice is removed, and hence the issue of collection of contributions from, and the allocation of benefits to, disparate self employed workers has been identified as a major obstacle to extending protection to the informal economy. It is upon this background that this study is aimed at evaluating the factors affecting access to formal social security schemes by members in the informal sector.

\section{PROBLEM ANALYSIS}

Pension reform around the world in recent decades has focused mainly on the formal sector. Consequently, many of those working in the informal sector have been left out of structured pension arrangements, particularly in developing countries thus a serious problem has risen given that this group is often made of low income earners, vulnerable to economic volatility and change. Despite the efforts which have been put in place by the Kenya government aimed at improving the social security coverage such as the establishment of NHIF which can be accessed even by those in the informal sector, the dream has not been fully realized. Workers in the informal economy still face clear and distinct threats to their human security and within this vulnerable economy, certain hierarchies pre-ordain further patterns of marginalization especially for women. The economy is deeply fragmented and diverse, with each group having its own needs. Most of the workers are officially invisible, which serves to reduce the pressure on government to consider and address their needs. It is upon this background that this study was undertaken to evaluate the factors influencing gender inequality in the access to formal social security schemes among members in the informal sector; a study of Laikipia East District.

\section{Note On Methodology}

This study employed descriptive survey design. Survey designs are used in preliminary and exploratory studies to allow researchers to gather information, summarize, present and interpret for the purpose of clarification [12]. By involving a broad category of members of the informal sector, the study fitted within the cross-sectional sub-types of descriptive survey study designs. This case study focused on members in the informal sectors in the Central division of Laikipia East District.

This area was preferred due to its uniqueness in terms of history, diversity and economic activities. Some of the striking features of the district include the expansive ranches, commonly owned by settlers and that employ many people in the area besides promoting tourism. The district is also a haven of horticulture and market gardening with expansive areas been used for flower farming an activity that is highly dominated by members of the informal sector. This promotes economic activities in the district to both formal and informal sectors. The unit of analysis for this study comprised of both men and women engaged in the informal sector activities in Central division of Laikipia East District.

Purposive sampling technique was used to sample Laikipia East District for the study. This was due to its uniqueness in terms of history, diversity and economic activities. Stratified sampling technique was used to group the targeted population according to the activities they carry out in the informal economy. This included those involved in activities such as: Jua Kali, small scale businesses, small scale crop farming, livestock rearing and those involved in casual job in the farms. 


\section{Results And Discussion}

Distribution of Respondents by Age

This study showed that age is an important factor in determining the productivity of an individual, thus understanding the relationship between age and economic productivity is very key in sociological studies. Given that older individuals are less productive, an aging working population can lower economic growth and decrease fiscal sustainability which has a bearing on the access to social security schemes. On the distribution of the respondents by age, the study found that that 37.5\% were between 36-45 years, 26\% were between $46-55$ years, $15 \%$ were between 26-35 years, $13.5 \%$ were between 19-25 years and $8 \%$ were above 55 years. From the findings of the study, it is clear that most of the respondents interviewed in the informal sector were between 3645 years. This is an indication of the productive age in life where many engage in productive work for their sustainability

\section{Distribution of the Respondents by Marital Status}

On the distribution of the respondents by marital status, this study found that $74 \%$ were married, $16 \%$ were single, $8 \%$ were widowed and $2 \%$ were divorced.

\section{Distribution of the Respondents by Level of Education}

On the distribution of the respondents by level of education, the study found that $32 \%$ of the respondents were secondary school graduates, $25 \%$ of the respondents had primary level of education, $21 \%$ did not go to school, $14 \%$ were graduates from college and $8 \%$ were University graduates. This is an indication that most of people (54\%) working in the informal sector went through secondary education.

\section{Distribution of the Respondents by their Duration of service in the Informal Sector}

On the distribution of the respondents by duration of service in the informal sector, the study found that $37 \%$ of the respondents had worked in the informal sector for a period between 6-10 years. The study also found that $22.5 \%$ had worked in the sector for a period between 3-5 years, $18.5 \%$ had worked in the sector for a period above 10 years, $14 \%$ had worked in the sector for a period between 1-2 years and that $8 \%$ had worked in the informal sector for a period less than 1 year. This is an indication that most of the respondents interviewed had worked in the informal sector for a period more than 5 years which may influence their level of awareness to the social security schemes.

\section{LEVEL OF ACCESS TO FORMAL SOCIAL SECURITY AMONG MEMBERS OF THE INFORMAL SECTOR IN LAIKIPIA EAST DISTRICT}

In establishing the gender disparity in the level of access to the social security schemes, the researcher aimed at finding out desire by the respondents to join the social security schemes and gender disparity in the level of accessibility of the schemes

\section{Gender, Age and Access to Social Security Schemes}

Age is an important factor influencing access to social security schemes. It influences the marital status, access to job opportunities and awareness. A cross-tabulation of gender, age and access to social security schemes revealed that there was gender diversity on the membership to social security schemes where more male were found to have higher access to the schemes across the ages except for age group between 36-45 years. Table 1 shows a cross tabulation of the respondents gender age and access to social security schemes.

(1) Table 1 Gender Age and Access to Social Security Schemes

\begin{tabular}{|c|c|c|c|c|c|c|c|c|}
\hline \multirow{2}{*}{\multicolumn{3}{|c|}{$\begin{array}{l}\text { Membership of Social Security } \\
\text { Scheme }\end{array}$}} & \multicolumn{5}{|c|}{ Age } & \multirow{3}{*}{$\frac{\text { Total }}{15}$} \\
\hline & & & \multirow{2}{*}{$\frac{19-25 y r s}{3}$} & \multirow{2}{*}{$\frac{26-35 \mathrm{yrs}}{1}$} & \multirow{2}{*}{$\frac{36-45 y r s}{6}$} & \multirow{2}{*}{$\frac{46-55 \mathrm{yrs}}{5}$} & \multirow{2}{*}{$\frac{\text { Above 55yrs }}{0}$} & \\
\hline Yes & Gender & Male & & & & & & \\
\hline & & Female & 1 & 2 & 4 & 3 & 1 & 11 \\
\hline & Total & & 4 & 3 & 10 & 8 & 1 & 26 \\
\hline \multirow[t]{3}{*}{ No } & Gender & Male & 11 & 17 & 26 & 29 & 6 & 89 \\
\hline & & Female & 12 & 10 & 39 & 15 & 9 & 85 \\
\hline & Total & & 23 & 27 & 65 & 44 & 15 & 174 \\
\hline
\end{tabular}

Source: Field Data (2013)

\section{Gender, Marital Status and Membership of Social Security Schemes}

Marital status is an important determinant to the access to social security schemes. The family costs such as medication and treatment influences couples to have access to schemes such as NHIF. On the other 
hand, being married is a journey into old age and thus people would prefer to start savings for their old age by joining schemes such as NSSF. Gender, marital status and membership of the social security schemes on Table 2 shows that marital status played an important role in the access to social security schemes where out of the 26 respondents who were members of the social security schemes, 22 were married while only 4 were single.

(2) Table 2: Gender, Marital Status and Membership of Social Security Schemes

\begin{tabular}{|c|c|c|c|c|c|c|c|}
\hline & & & \multicolumn{4}{|c|}{ Marital Status } & \multirow[b]{2}{*}{ Total } \\
\hline \multicolumn{3}{|c|}{ Member of Social Security Scheme } & Married & Single & Divorced & Widowed & \\
\hline \multirow[t]{3}{*}{ Yes } & Gender & Male & 13 & 2 & & & 15 \\
\hline & & Female & 9 & 2 & & & 11 \\
\hline & Total & & 22 & 4 & & & 26 \\
\hline \multirow[t]{3}{*}{ No } & Gender & Male & 65 & 15 & 2 & 7 & 89 \\
\hline & & Female & 61 & 13 & 2 & 9 & 85 \\
\hline & Total & & 126 & 28 & 4 & 16 & 174 \\
\hline
\end{tabular}

Source: Field Data (2013)

\section{Gender, Level of Education and Membership of Social Security Schemes}

This study showed that level of education influences the knowledge on the availability and importance of the schemes. Table 3 shows that 15 (7.5\%) of the male respondents had access to the social security schemes while $11(5.5 \%)$ of female respondents were members of the social security schemes. At the college and university level, there were more female accessing the social security schemes $7(3.5 \%)$ compared to male 5 $(2.5 \%)$. This was not the case among those in the lower levels of education where more males accessed the schemes compared to female. This is an indication that education narrowed the gender inequality gap on the membership to social security schemes.

(3) Table 3: Gender, Level of Education and Membership of Social Security Schemes

\begin{tabular}{|c|c|c|c|c|c|c|c|c|}
\hline \multirow{2}{*}{\multicolumn{3}{|c|}{$\begin{array}{l}\text { Membership of Social } \\
\text { Security Schemes }\end{array}$}} & \multicolumn{5}{|c|}{ Education Level } & \multirow{3}{*}{$\begin{array}{c}\text { Total } \\
15\end{array}$} \\
\hline & & & \multirow{2}{*}{$\begin{array}{c}\begin{array}{c}\text { Did not go } \\
\text { to School }\end{array} \\
5\end{array}$} & \multirow{2}{*}{$\frac{\text { Primary }}{4}$} & \multirow{2}{*}{$\frac{\text { Secondary }}{1}$} & \multirow{2}{*}{$\frac{\text { College }}{3}$} & \multirow{2}{*}{$\frac{\text { University }}{2}$} & \\
\hline Yes & Gender & Male & & & & & & \\
\hline & & Female & 1 & 2 & 1 & 3 & 4 & 11 \\
\hline & Total & & 6 & 6 & 2 & 6 & 6 & 26 \\
\hline \multirow[t]{3}{*}{ No } & Gender & Male & 18 & 18 & 37 & 10 & 6 & 89 \\
\hline & & Female & 19 & 25 & 26 & 12 & 3 & 85 \\
\hline & Total & & 37 & 43 & 63 & 22 & 9 & 174 \\
\hline
\end{tabular}

Source: Field Data (2013)

Those who did not have access to the social security schemes were asked to indicate whether they desired to join the schemes. Table 4 shows the results of a cross-tabulation of gender and the desire to join the schemes.

In an interview with the key informants, it was found that men in the informal sector have more access to the schemes compared to women. The key informants explained that more women were involved in casual part time work which erodes their eligibility from many formal social security schemes. They also mentioned arising out of their interactions with informal sector members, women often complain of the high rates of contribution to the schemes.

Table 4: Cross Tabulation of Gender and the Desire to join the Social Security Schemes

\begin{tabular}{|c|c|c|c|c|}
\hline & & \multicolumn{2}{|c|}{ Desire to join Social Security Schemes } & \multirow[b]{2}{*}{ Total } \\
\hline & & No & Yes & \\
\hline \multirow[t]{2}{*}{ Gender } & Male & 32 & 72 & 104 \\
\hline & Female & 31 & 65 & 96 \\
\hline Total & & 63 & 137 & 200 \\
\hline
\end{tabular}

Source: Field Data (2013)

Findings in table 4 revealed that showed that 137 (68\%) of the respondents indicated that they had the desires to join the social security schemes while 63 (32\%) indicated that they did not have the desire to join the 
schemes. Among those who had the desire to join social security schemes, $72(53 \%)$ were male while $65(47 \%)$ were female. This is an indication that that most of the men and women in the informal sector who do not have access to social security schemes had the desire to join the schemes. Table 5 shows the results of a crosstabulation of gender, marital status and desire to join the schemes.

Table 5: Cross-tabulation of Gender, Marital Status and Desire to Join Social Security Scheme

\begin{tabular}{|c|c|c|c|c|c|c|c|}
\hline \multirow{2}{*}{\multicolumn{3}{|c|}{ Desire to join the Social Security Schemes }} & \multicolumn{4}{|c|}{ Marital Status } & \multirow[b]{2}{*}{ Total } \\
\hline & & & Married & Single & Divorced & Widowed & \\
\hline \multirow[t]{3}{*}{ No } & Gender & Male & 17 & 10 & 0 & 5 & 32 \\
\hline & & Female & 21 & 4 & 0 & 6 & 31 \\
\hline & Total & & 38 & 14 & 0 & 11 & 63 \\
\hline \multirow[t]{3}{*}{ Yes } & Gender & Male & 61 & 7 & 2 & 2 & 72 \\
\hline & & Female & 49 & 11 & 2 & 3 & 65 \\
\hline & Total & & 110 & 18 & 4 & 5 & 137 \\
\hline
\end{tabular}

Source: Field Data (2013)

Table 5 shows that there was gender disparity on the desire to join the social security schemes where $61(30.5 \%)$ of the married men had the desire to join the schemes while $49(24.5 \%)$ of the married female desired to join the schemes.

\section{Gender and Level of Accessibility to the Schemes}

Findings of this study showed that gender influences the level of accessibility to the schemes in different ways. Considering the economic aspects, gender influences access to job opportunities among the members of the informal sector. Table 6 shows that $18(9 \%)$ of the male respondents indicated that the schemes were accessible while $13(6.5 \%)$ of the female respondents indicated that the schemes were very easy to access. This is an indication that there was gender disparity on the access to the social security schemes.

Table 6: Gender and Level of Accessibility to the Schemes

\begin{tabular}{|c|c|c|c|c|c|c|c|c|c|c|c|}
\hline & & \multicolumn{10}{|c|}{ Level of Accessibility } \\
\hline & & \multicolumn{2}{|c|}{$\begin{array}{l}\text { Very easy to } \\
\text { access }\end{array}$} & \multicolumn{2}{|c|}{ Easy to access } & \multicolumn{2}{|c|}{$\begin{array}{l}\text { Difficult to } \\
\text { access }\end{array}$} & \multicolumn{2}{|c|}{$\begin{array}{l}\text { Very difficult to } \\
\text { access }\end{array}$} & \multicolumn{2}{|c|}{ Total } \\
\hline & & $\mathbf{F}$ & $\%$ & $\mathbf{F}$ & $\%$ & $\mathbf{F}$ & $\%$ & $\mathbf{F}$ & $\%$ & $\mathbf{F}$ & $\%$ \\
\hline Gender & Male & 18 & 9 & 25 & 12.5 & 35 & 37.7 & 26 & 13 & 104 & 52 \\
\hline & Female & 13 & 6.5 & 16 & 8 & 37 & 18.5 & 30 & 15 & 96 & 48 \\
\hline Total & & 31 & 15.5 & 41 & 20.5 & 72 & 36 & 56 & 28 & 200 & 100 \\
\hline
\end{tabular}

Source: Field Data (2013)

In an interview with the officers from the NSSF and NHIF on the proportion of women and men in the informal sectors accessing social security schemes, the study found that less than $5 \%$ of women in the informal sector had access to social security schemes while less than $10 \%$ of men in the informal sector had access to social security schemes. Based on these findings of the study, it can be argued that access to social security schemes among those in the informal sector is low with access among female being lower than the male.

\section{EFFECT OF THE LEVEL OF AWARENESS ON ACCESS TO FORMAL SOCIAL SECURITY SCHEMES AMONG MEMBERS OF THE INFORMAL SECTOR IN LAIKIPIA EAST DISTRICT}

To test on the awareness of the social security schemes among the members of the informal sector, this study tested the level of awareness of different schemes among the respondents.

\section{Gender and Awareness of NSSF (National Social Security Fund)}

Gender is perceived to influence the level of awareness of the social security schemes in that those who have high education levels are better placed to know of the availability of the schemes as opposed to those with low levels of education. Table 7 shows the findings of a cross-tabulation between gender and awareness on National Social Security Fund.

Table 7: Gender and Awareness of NSSF (National Social Security Fund)

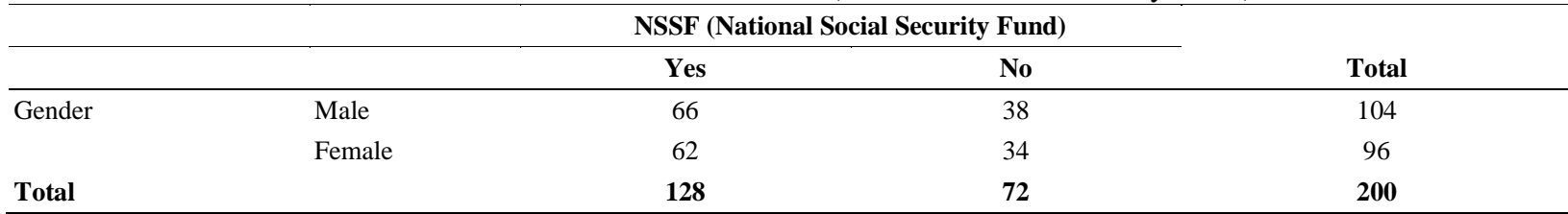


Source: Field Data (2013)

The finding on table 7 shows that 66 (33\%) of male respondents were aware of NSSF while $62(31 \%)$ of the female respondents were aware of the scheme. This is an indication of gender inequality on awareness on National Social Security Fund (NSSF).

In an interview with the key informants, they mentioned that high illiteracy levels among members of the informal sector to me a major hindrance to access to social security schemes. They further mentioned that illiteracy levels affect public education on the available schemes. Awareness is therefore considered to be a major barrier to the access to social security schemes according to the officers from the NSSF and NHIF.

\section{Gender, level of education and Awareness on NSSF}

Level of education is an important factor in the determination of the level of awareness of the schemes among the members of the informal sector. Table 8 shows that $43(21.5 \%)$ of the respondents aware of NSSF had secondary level of education. Female respondents who had college and university education $(9.5 \%)$ were found to be more aware of the schemes than the male counterparts $(6.5 \%)$ who had the same levels of education. This disparity is attributed to the level of education among the respondents. Education levels lead to the exposure and wider understanding of the schemes in terms of their availability and importance resulting into the difference in the level of awareness of the schemes among the members of the informal sector.

Table 8: Gender, level of education and Awareness on NSSF

\begin{tabular}{|c|c|c|c|c|c|c|c|c|}
\hline & & & \multicolumn{5}{|c|}{ Education Level } & \multirow[b]{2}{*}{ Total } \\
\hline \multicolumn{3}{|c|}{$\begin{array}{l}\text { Awareness on National Social } \\
\text { Security Fund (NSSF }\end{array}$} & Primary & Secondary & College & University & $\begin{array}{l}\text { Did not go to } \\
\text { School }\end{array}$ & \\
\hline \multirow[t]{3}{*}{ Yes } & Gender & Male & 15 & 24 & 10 & 2 & 15 & 66 \\
\hline & & Female & 15 & 19 & 13 & 6 & 9 & 62 \\
\hline & Total & & 30 & 43 & 23 & 8 & 24 & 128 \\
\hline \multirow[t]{3}{*}{ No } & Gender & Male & 7 & 14 & 3 & 6 & 8 & 38 \\
\hline & & Female & 12 & 8 & 2 & 1 & 11 & 34 \\
\hline & Total & & 19 & 22 & 5 & 7 & 19 & 72 \\
\hline
\end{tabular}

Source: Field Data (2013)

\section{Gender, Duration of Service in the Informal Sector and Awareness on National Social Security Fund}

Duration of services is an indicator for the exposure in the sector. The duration of service in the informal sector is therefore perceived to influence awareness of the schemes and even access as it dictates the income one generates and the knowledge on the available schemes. The more one stays in a particular sector, the more he/she gets exposed to the sector which informs his/her decisions. Table 9 shows 48 (24\%) of the respondents who had served in the informal sector for a period between 6-10 years were aware of the NSSF. There was also gender disparity on the awareness of the scheme where 28 (14\%) were male while $20(10 \%)$ were female. It can therefore be argued that duration of service in the informal sector informed the level of awareness among those in the informal sector which further revealed disparity where men were considered to be more aware of the schemes compared to their female counterparts.

Table 9: Gender, Duration of Service in the Informal Sector and Awareness on National Social Security Fund Duration of Service

\begin{tabular}{|c|c|c|c|c|c|c|c|c|}
\hline \multirow{2}{*}{\multicolumn{3}{|c|}{$\begin{array}{l}\text { Awareness on National Social } \\
\text { Security Fund }\end{array}$}} & \multicolumn{5}{|c|}{ Duration of Service } & \multirow[b]{2}{*}{ Total } \\
\hline & & & \multirow{2}{*}{$\begin{array}{c}\begin{array}{c}\text { Less than a } \\
\text { year }\end{array} \\
4\end{array}$} & \multirow{2}{*}{$\frac{1-2 \text { Years }}{8}$} & \multirow{2}{*}{$\frac{3-5 \text { Years }}{15}$} & \multirow{2}{*}{$\frac{6-10 \text { Years }}{28}$} & \multirow{2}{*}{$\frac{\text { Above } 10 \text { years }}{11}$} & \\
\hline Yes & Gender & Male & & & & & & 66 \\
\hline & & Female & 5 & 9 & 13 & 20 & 15 & 62 \\
\hline & Total & & 9 & 17 & 28 & 48 & 26 & 128 \\
\hline \multirow[t]{3}{*}{ No } & Gender & Male & 3 & 4 & 12 & 10 & 9 & 38 \\
\hline & & Female & 4 & 7 & 5 & 16 & 2 & 34 \\
\hline & Total & & 7 & 11 & 17 & 26 & 11 & 72 \\
\hline
\end{tabular}

Source: Field Data (2013)

\section{Gender, Level of Education and Awareness on NHIF (National Hospital Insurance Fund)}

This study showed that the level of awareness affects access to social security schemes especially NHIF. Being that heath is very crucial even among the informal sector, those who happen to know the benefits of such schemes are moved to find membership for the schemes where education becomes central. Table 10 
shows that $74(37 \%)$ of women were aware of NHIF while $63(31.5 \%)$ of male were aware of the scheme. This is an indication that there was gender disparity on the awareness on NHIF with female being more aware than the male. This disparity can be attributed to the fact that women benefit more on from the NHIF through frequent visit to the hospitals during their pre-natal and post natal stages compared to their male counterparts.

Table 10: Gender, Level of Education and Awareness on NHIF

\begin{tabular}{|c|c|c|c|c|c|c|c|c|}
\hline \multirow{2}{*}{\multicolumn{3}{|c|}{$\begin{array}{l}\text { Awareness on National } \\
\text { Hospital Insurance Fund }\end{array}$}} & \multicolumn{5}{|c|}{ Education Level } & \multirow{3}{*}{$\frac{\text { Total }}{63}$} \\
\hline & & & \multirow{2}{*}{$\begin{array}{c}\text { Did not go to } \\
\text { School }\end{array}$} & \multirow{2}{*}{$\frac{\text { Primary }}{15}$} & \multirow{2}{*}{$\frac{\text { Secondary }}{22}$} & \multirow{2}{*}{$\frac{\text { College }}{8}$} & \multirow{2}{*}{$\frac{\text { University }}{3}$} & \\
\hline Yes & Gender & Male & & & & & & \\
\hline & & Female & 14 & 22 & 19 & 12 & 7 & 74 \\
\hline & Total & & 29 & 37 & 41 & 20 & 10 & 137 \\
\hline \multirow[t]{3}{*}{ No } & Gender & Male & 8 & 7 & 16 & 5 & 5 & 41 \\
\hline & & Female & 6 & 5 & 8 & 3 & 0 & 22 \\
\hline & Total & & 14 & 12 & 24 & 8 & 5 & 63 \\
\hline
\end{tabular}

Source: Field Data (2013)

\section{Gender, Level of Awareness on NSSF and the Duration of Service}

Duration of service influences the level of awareness of the schemes as it reflects on the exposure of those in the sector. The finding on Table 11 shows that those who had been serving in the informal sector were more aware of the social security schemes than those who has served for a short duration. Duration of service in the informal sector is therefore considered to be a factor affecting access to social security schemes.

Table 11: Gender, Level of Awareness on NSSF and the Duration of Service

\begin{tabular}{|c|c|c|c|c|c|c|c|c|}
\hline & & & \multicolumn{5}{|c|}{ Duration of Service } & \multirow[b]{2}{*}{ Total } \\
\hline \multicolumn{3}{|c|}{$\begin{array}{l}\text { Awareness on National Hospital } \\
\text { Insurance Fund }\end{array}$} & $\begin{array}{l}\text { Less than a } \\
\text { year }\end{array}$ & 1-2 Years & 3-5 Years & 6-10 Years & $\begin{array}{l}\text { Above } 10 \\
\text { years }\end{array}$ & \\
\hline \multirow[t]{3}{*}{ Yes } & Gender & Male & 4 & 7 & 15 & 26 & 11 & 63 \\
\hline & & Female & 7 & 13 & 15 & 26 & 13 & 74 \\
\hline & Total & & 11 & 20 & 30 & 52 & 24 & 137 \\
\hline \multirow[t]{3}{*}{ No } & Gender & Male & 3 & 5 & 12 & 12 & 9 & 41 \\
\hline & & Female & 2 & 3 & 3 & 10 & 4 & 22 \\
\hline & Total & & 5 & 8 & 15 & 22 & 13 & 63 \\
\hline
\end{tabular}

Source: Field Data (2013)

\section{Gender, Age bracket and Awareness on Non Contributory Pension Schemes}

This study showed that age influences the marital status and the responsibility of those in the informal sector. Those who are young may not realize the importance of social security schemes as opposed to the elderly and those who are married. The finding on Table 12 shows that, most of the respondents who were aware of the non contributory pension schemes were 46 years and above. This is an indication that age was an important factor in determining the knowledge on non contributory pension schemes. This is based on the fact that the scheme only applies to those who had been members of the schemes before their retirement. Regarding gender inequality, it was evident that male respondents were more aware of the scheme compared to the female.

Table 12: Gender, Age bracket and Awareness on Non Contributory Pension Schemes

\begin{tabular}{|c|c|c|c|c|c|c|c|c|}
\hline \multirow{2}{*}{\multicolumn{3}{|c|}{$\begin{array}{l}\text { Awareness on Non Contributory } \\
\text { Scheme }\end{array}$}} & \multicolumn{5}{|c|}{ Age } & \multirow[b]{2}{*}{ Total } \\
\hline & & & $19-25 y r s$ & $26-25 \mathrm{yrs}$ & $36-45 \mathrm{yrs}$ & $46-55 \mathrm{yrs}$ & Above 55yrs & \\
\hline \multirow[t]{3}{*}{ Yes } & Gender & Male & 0 & 1 & 2 & 3 & 2 & 8 \\
\hline & & Female & 0 & 1 & 2 & 2 & 1 & 6 \\
\hline & Total & & & 2 & 4 & 5 & 3 & 14 \\
\hline \multirow[t]{3}{*}{ No } & Gender & Male & 14 & 17 & 30 & 31 & 4 & 96 \\
\hline & & Female & 13 & 11 & 41 & 16 & 9 & 90 \\
\hline & Total & & 27 & 28 & 71 & 47 & 16 & 186 \\
\hline
\end{tabular}

Source: Field Data (2013)

Gender, Age and Awareness of Old Persons Cash Transfer 
Table 13 shows that most of the people who were aware of the old persons cash transfer were 46 years and above. This is an indication that age was a factor in determining awareness on old persons cash transfer scheme. Female respondents were more aware of the old persons cash transfer.

Table 13: Gender, Age and Awareness of Old Persons Cash Transfer

\begin{tabular}{|c|c|c|c|c|c|c|c|c|}
\hline \multirow{2}{*}{\multicolumn{3}{|c|}{$\begin{array}{l}\text { Awareness on Older persons } \\
\text { cash transfer }\end{array}$}} & \multicolumn{5}{|c|}{ Age } & \multirow[b]{2}{*}{ Total } \\
\hline & & & $19-25 \mathrm{yrs}$ & $26-25 \mathrm{yrs}$ & $36-45 \mathrm{yrs}$ & $46-55 \mathrm{yrs}$ & Above $55 \mathrm{yrs}$ & \\
\hline \multirow[t]{3}{*}{ Yes } & Gender & Male & 2 & 4 & 8 & 6 & 5 & 25 \\
\hline & & Female & 3 & 7 & 3 & 12 & 7 & 32 \\
\hline & Total & & 5 & 11 & 11 & 18 & 12 & 57 \\
\hline \multirow[t]{3}{*}{ No } & Gender & Male & 13 & 14 & 30 & 20 & 2 & 79 \\
\hline & & Female & 9 & 5 & 33 & 14 & 2 & 64 \\
\hline & Total & & 22 & 19 & 63 & 34 & 4 & 143 \\
\hline
\end{tabular}

Source: Field Data (2013)

Gender, Level of Education and Awareness on Older Persons Cash Transfer

A cross-tabulation of gender, level of education and awareness of old persons cash transfers showed that knowledge on older persons cash transfer was well spread across the education levels. This is attributed to the fact that it was recently introduced and mostly those in the rural areas get access to the funds thus creating awareness on the schemes. The findings are presented in Table 14.

Table 14: Gender, Level of Education and Awareness on Older Persons Cash Transfer

\begin{tabular}{lllcccccc}
\hline & & \multicolumn{7}{c}{ Education Level } \\
\cline { 3 - 8 } $\begin{array}{l}\text { Awareness on Older persons } \\
\text { cash transfer }\end{array}$ & & $\begin{array}{c}\text { Did not go } \\
\text { to School }\end{array}$ & Primary & Secondary & College & University & Total \\
\hline Yes & Gender & Male & 6 & 6 & 8 & 1 & 4 & 25 \\
& & Female & 7 & 8 & 11 & 4 & 2 & 32 \\
& & $\mathbf{1 3}$ & $\mathbf{1 4}$ & $\mathbf{1 9}$ & $\mathbf{5}$ & $\mathbf{2}$ & $\mathbf{5 7}$ \\
Notal & & 17 & 16 & 26 & 12 & 6 & 79 \\
& Gender & Male & 13 & 19 & 20 & 11 & 3 & 64 \\
& Female & $\mathbf{3 0}$ & $\mathbf{3 5}$ & $\mathbf{4 6}$ & $\mathbf{2 3}$ & $\mathbf{1 3}$ & $\mathbf{1 4 3}$ \\
\hline
\end{tabular}

Source: Field Data (2013)

Gender, Source of Income and Non awareness of Social Security Schemes

Source of income is a major determinant to the access to social security schemes. It determines the possibility of remitting the monthly payments to the schemes. Table 15 shows that there was gender disparity in terms of none awareness of the available social security schemes where $21(10.5 \%)$ of female respondents interviewed were found not to be aware of any of the schemes while $14(7 \%)$ of male respondents were not aware of any of the social security schemes.

Table 15: Gender, Source of Income and Non awareness of Social Security Schemes

\begin{tabular}{|c|c|c|c|c|c|c|c|c|c|}
\hline \multirow{2}{*}{\multicolumn{3}{|c|}{$\begin{array}{l}\text { Not aware of any of the } \\
\text { schemes }\end{array}$}} & \multicolumn{6}{|c|}{ Source of Income } & \multirow{3}{*}{$\frac{\text { Total }}{14}$} \\
\hline & & & \multirow{2}{*}{$\begin{array}{c}\begin{array}{c}\text { Jua Kali } \\
\text { (Mechanics, } \\
\text { Capenter) }\end{array} \\
9\end{array}$} & \multirow{2}{*}{$\begin{array}{c}\begin{array}{c}\text { Small scale } \\
\text { business }\end{array} \\
0\end{array}$} & \multirow{2}{*}{$\begin{array}{c}\begin{array}{c}\text { Small scale } \\
\text { crop farming }\end{array} \\
2\end{array}$} & \multirow{2}{*}{$\begin{array}{c}\begin{array}{c}\text { Livestock } \\
\text { rearing }\end{array} \\
0\end{array}$} & \multirow{2}{*}{$\begin{array}{c}\begin{array}{c}\text { Casual } \\
\text { jobs }\end{array} \\
0\end{array}$} & \multirow{2}{*}{$\begin{array}{c}\begin{array}{c}\text { Service } \\
\text { industry }\end{array} \\
3\end{array}$} & \\
\hline Yes & Gender & Male & & & & & & & \\
\hline & & Female & 0 & 5 & 4 & 2 & 3 & 7 & 21 \\
\hline & Total & & 9 & 5 & 6 & 2 & 3 & 10 & 35 \\
\hline \multirow[t]{3}{*}{ No } & Gender & Male & 33 & 8 & 11 & 15 & 7 & 16 & 90 \\
\hline & & Female & 0 & 34 & 16 & 3 & 13 & 9 & 75 \\
\hline & Total & & 33 & 42 & 27 & 18 & 20 & 25 & 165 \\
\hline
\end{tabular}

Source: Field Data (2013)

Respondents were asked to mention other factors affecting the awareness on social security schemes among the members of the informal sectors. The study found that ignorance among the members of the society was a major challenge to awareness of the schemes among the members of the informal sector. 
EFFECT OF ECONOMIC FACTORS ON ACCESS TO FORMAL SOCIAL SECURITY SCHEMES AMONG MEMBERS OF THE INFORMAL SECTOR IN LAIKIPIA EAST DISTRICT

\section{Sources of Income among the Members of the Informal Sector}

Sources of income influences access to social security schemes as it affects the ability to pay for the schemes on a monthly basis. It was therefore necessary that the sources of income of the respondents be established in order to determine its influence on the access to social security schemes among the members of the informal sector. Figure 1 presents the findings of the study.

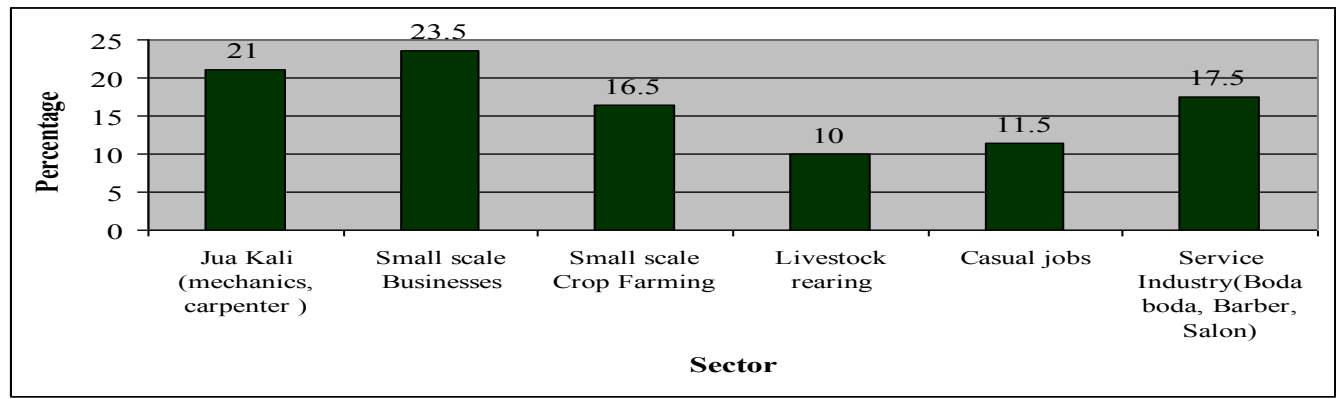

Figure 1: Sources of Income among the Members of the Informal Sector Source: Field Data (2013)

Findings on Figure 1 shows that $23.5 \%$ of the respondents indicated that they engaged in small scale businesses such as operating butcheries, M-PESA attendant, hawking, selling shoes and mobile phone repair. It also turned out that $21 \%$ were in the Jua Kali sector such as mechanics, tailors, and carpenters. The study also found that $17.5 \%$ of the respondents were in the service industry such as boda boda operators, barbing, salon business, shoe repair, shoe shiner, hotel waiter, watchman, matatu conductor and herding. It was finally found that $16.5 \%$ small scale crop farmers, $11.5 \%$ were casual job workers and $10 \%$ were livestock farmers. From the findings of the study it can be concluded that those in the informal sector in Laikipia District engage in divergent economic activities to earn a living.

\section{Gender and Source of Income}

This study showed that ender is a major determinant to sources of income. It dictates the nature of activities the members of the informal sector involve in and thus influences the amount of income they generate. Table 16 presents the findings of a cross-tabulation of source of gender and source of income for the respondents

Table 16: Gender and Source of Income

\begin{tabular}{|c|c|c|c|c|c|c|c|}
\hline & & \multicolumn{5}{|c|}{ Gender } & \multirow[b]{2}{*}{ Total } \\
\hline & & & Male & & Female & & \\
\hline & & $\mathrm{F}$ & $\%$ & $\mathrm{~F}$ & $\%$ & $\mathrm{~F}$ & $\%$ \\
\hline \multirow{6}{*}{$\begin{array}{l}\text { Source of } \\
\text { Income }\end{array}$} & $\begin{array}{l}\text { Jua Kali (Mechanics, } \\
\text { Capenter) }\end{array}$ & 42 & 21 & 0 & 0 & 42 & 21 \\
\hline & Small scale business & 8 & 4 & 39 & 19.5 & 47 & 23.5 \\
\hline & $\begin{array}{l}\text { Small scale crop } \\
\text { farming }\end{array}$ & 13 & 6.5 & 20 & 10 & 33 & 16.5 \\
\hline & Livestock rearing & 15 & 7.5 & 5 & 2.5 & 20 & 10 \\
\hline & Casual jobs & 7 & 3.5 & 16 & 8 & 23 & 11.5 \\
\hline & Service industry & 19 & 9.5 & 16 & 8 & 35 & 17.5 \\
\hline Total & & 104 & 52 & 96 & 48 & 200 & 100 \\
\hline
\end{tabular}

Source: Field Data (2013)

Table 16 shows that male respondents were dominant in the Jua Kali Sector 42 (21\%). Female respondents were found to be dominant in small scale business 39 (19.5\%). Casual jobs were dominated by female respondents while service industry was dominated by male respondents. Considering all the sectors, most of the respondents in the informal sector interviewed were engaged in small scale business.

\section{Ability to Remit the Monthly Contributions}

The ability to remit the monthly remissions is a factor influencing access to the social security schemes. It is dictated by the amount of income generated by an individual in the informal sector. Table 17 presents the findings on the ability of the respondents on the remission of monthly contributions to the schemes. 
Gender Inequality in Access to Formal Social Security Schemes among Members in the Informal

Table 17: Ability to Remit the Monthly Contributions

\begin{tabular}{lccccccc}
\hline & \multicolumn{2}{c}{ Male } & \multicolumn{2}{c}{ Female } & \multicolumn{2}{c}{ Total } \\
\hline Response & $\mathbf{f}$ & $\mathbf{\%}$ & $\mathbf{f}$ & $\mathbf{\%}$ & $\mathbf{f}$ & $\mathbf{\%}$ \\
Yes & 56 & 54 & 21 & 22 & 77 & 38.5 \\
No & 48 & 46 & 75 & 78 & 123 & 61.5 \\
Total & $\mathbf{1 0 4}$ & $\mathbf{1 0 0}$ & $\mathbf{9 6}$ & $\mathbf{1 0 0}$ & $\mathbf{2 0 0}$ & $\mathbf{1 0 0 . 0}$ \\
\hline
\end{tabular}

Source: Field Data (2013)

Findings on Table 17 shows that $61.5 \%$ of the respondents indicated that they could not afford to remit the contributions because their incomes could not allow while $38.5 \%$ (constituting $54 \%$ male and $22 \%$ female) indicated that they could comfortably remit the contributions. This shows that majority of male respondents were at a position to remit the contributions to the schemes compare to female.

Those who indicated that they could comfortably remit to the social security schemes were asked to indicate the amount of money they could remit to the schemes on a monthly basis. Table 18 presents the findings of a cross-tabulation of gender and amount payable to the schemes.

Table 18: Gender and Amount Payable

\begin{tabular}{lccccccccc}
\hline & \multicolumn{1}{c}{ Amount Payable } \\
\cline { 2 - 9 } & $1-100$ & $101-200$ & $201-300$ & $301-400$ & $401-500$ & $501-600$ & $601-700$ & $701-800$ & Total \\
\hline Male & 6 & 11 & 12 & 10 & 8 & 4 & 3 & 2 & 56 \\
Female & 11 & 4 & 3 & 2 & 1 & 0 & 0 & 0 & 21 \\
Total & $\mathbf{1 7}$ & $\mathbf{1 5}$ & $\mathbf{1 5}$ & $\mathbf{1 2}$ & $\mathbf{9}$ & $\mathbf{4}$ & $\mathbf{3}$ & $\mathbf{2}$ & $\mathbf{7 7}$ \\
\hline
\end{tabular}

Source: Field Data (2013)

Table 18 shows that 12 (16\%) of those who could remit the monthly contribution between Ksh 201-300 were male while $11(14 \%)$ were female respondents who could remit between Ksh 1-100. The findings of the study also reveal that $56(73 \%)$ of the respondents who could remit the monthly contributions were male while $21(27 \%)$ were female respondents. This is an indication of gender disparity in the access to the schemes pegged on the economic factors.

In an interview with the key informants on the economic factors affect access to social security among the members of the informal sector, the following were mentioned, high poverty levels, lack of economic power among women, lack of employment and inadequate infrastructure. They mentioned that the fact that women typically stay in the labour market for fewer years, are more likely to work informally, have lower earnings, and a shorter and more interrupted employment history than men means that they receive considerably lower benefits.

\section{Level of education and Monthly remission to Social Security Schemes}

This study showed that the level of education has a bearing on the amount of income earned by the members of the informal sector. This in turn influences the amount of money to be remitted by the schemes. Table 4.19 presents the findings of a cross-tabulation of level of education of the respondents and payable monthly remissions.

Table 19: Level of education and Monthly remission to Social Security Schemes

\begin{tabular}{|c|c|c|c|c|c|c|c|c|c|}
\hline \multirow{2}{*}{$\begin{array}{l}\text { Level of } \\
\text { Education }\end{array}$} & \multicolumn{8}{|c|}{ Amount Payable } & \multirow[b]{2}{*}{ Total } \\
\hline & $1-100$ & $101-200$ & $201-300$ & $301-400$ & $401-500$ & $501-600$ & $601-700$ & $701-800$ & \\
\hline $\begin{array}{l}\text { Did not go to } \\
\text { School }\end{array}$ & 4 & 2 & 3 & 3 & 0 & 0 & 1 & 1 & 14 \\
\hline Primary & 7 & 1 & 2 & 3 & 2 & 2 & 1 & 1 & 19 \\
\hline Secondary & 3 & 6 & 4 & 4 & 6 & 2 & 1 & 0 & 25 \\
\hline College & 3 & 4 & 5 & 2 & 0 & 0 & 0 & 0 & 14 \\
\hline University & 0 & 0 & 0 & 0 & 1 & 1 & 2 & 1 & 5 \\
\hline Total & 17 & 15 & 14 & 12 & 9 & 5 & 5 & 3 & 77 \\
\hline
\end{tabular}

Source: Field Data (2013)

Table 19 shows that level of education was an evident factor influencing the contribution especially among University student who were at a position to pay with their potentials ranging between Ks $400-800$ per month. 


\section{Source of Income and Monthly Remission to the Schemes}

This study showed that source of income influences the amount of money generated from the activities in the informal sector. Some of the activities generate more income than other and at the same time attracts different genders in different proportions. Table 20 shows the findings of a correlation of source of income and potential monthly contributions among the respondents.

Table 20: Source of Income and Monthly Remission to the Schemes

\begin{tabular}{|c|c|c|c|c|c|c|c|c|c|}
\hline \multirow[t]{2}{*}{ Source of Income } & \multicolumn{8}{|c|}{ Amount Payable } & \multirow[b]{2}{*}{ Total } \\
\hline & $1-100$ & $101-200$ & $201-300$ & $301-400$ & $401-500$ & $501-600$ & $601-700$ & $701-800$ & \\
\hline $\begin{array}{l}\text { Jua Kali } \\
\text { (Mechanics, } \\
\text { Carpenter) }\end{array}$ & 4 & 4 & 2 & 3 & 5 & 3 & 2 & 1 & 24 \\
\hline Small scale business & 4 & 3 & 3 & 0 & 0 & 0 & 1 & 0 & 11 \\
\hline Livestock rearing & 1 & 3 & 2 & 3 & 1 & 1 & 0 & 0 & 11 \\
\hline Casual jobs & 2 & 1 & 2 & 2 & 0 & 0 & 0 & 0 & 7 \\
\hline Service industry & 4 & 2 & 3 & 3 & 2 & 0 & 0 & 1 & 15 \\
\hline Total & 17 & 15 & 15 & 12 & 9 & 4 & 3 & 2 & 77 \\
\hline
\end{tabular}

Source: Field Data (2013)

Findings on Table 20 above shows that $24(31 \%)$ of those who could remit the monthly contributions to the schemes were in the jua kali sector. It was also evident that those in the jua kali were at a position to remit higher monthly contributions compared to those from other sectors.

Respondents were further asked to mention some of the economic factors affecting access to social security schemes among the members of the informal sector. The following factors were mentioned: high monthly remission to the schemes, high rate of taxes, lack of stable jobs and poverty.

EFFECT OF GOVERNMENT POLICIES ON ACCESS TO FORMAL SOCIAL SECURITY AMONG MEMBERS OF THE INFORMAL SECTOR IN LAIKIPIA EAST DISTRICT

Gender, Awareness on policies Governing Access to the Social Security Schemes

Respondents were asked to indicate whether they were aware of the government policies governing social security schemes. Table 21 presents the findings of a cross-tabulation of gender and awareness on government policies governing social security schemes.

Table 21: Gender, Awareness on policies Governing Access to the Social Security Schemes

\begin{tabular}{llccc}
\hline & & \multicolumn{2}{c}{ Awareness of policies governing Social Security } & \multirow{2}{*}{ Total } \\
\cline { 3 - 4 } & & Yes & No & \\
\hline \multirow{2}{*}{ Gender } & Male & 21 & 83 & 104 \\
& Female & 9 & 87 & 96 \\
Total & & $\mathbf{3 0}$ & $\mathbf{1 7 0}$ & $\mathbf{2 0 0}$ \\
\hline
\end{tabular}

Source: Field Data (2013)

Findings on Table 21 shows that only $30(15 \%)$ of the respondents interviewed indicated that they were aware of the policies governing social security schemes. There was also evident gender disparity in the knowledge on awareness of the policies where 21 (10.5\%) were male while $9(4.5 \%)$ were female. Awareness on the policies governing social security schemes is therefore perceived to affect access to the schemes among members of the informal sector.

Those who indicated that they were aware of government policies affecting access to social security were further asked to mention the policies and how they perceived them to affect access to the schemes. They mentioned: the minimum amounts to be remitted to the schemes on a monthly basis which is perceived to be so high and high taxes which prohibits subscription to the schemes. They also mentioned knowledge on the openness to access to the schemes such as NHIF by members of the informal sector affected access to the schemes as majority of the respondents believed that the schemes could only be accessed by those in the formal employment. 
Table 22 presents the findings of a cross-tabulation of level of education and awareness of government policies governing social security schemes.

Table 22: Cross-tabulation of the level of Education and Awareness of policies governing Social Security Schemes

\begin{tabular}{llccc}
\hline & & \multicolumn{3}{c}{$\begin{array}{c}\text { Awareness of policies governing Social Security } \\
\text { Schemes }\end{array}$} \\
\cline { 3 - 5 } & & Yes & No & Total \\
\hline \multirow{3}{*}{ Education level } & Did not go to School & 2 & 40 & 42 \\
& Primary & 4 & 45 & 59 \\
& Secondary & 7 & 20 & 28 \\
& College & 8 & 6 & 15 \\
Total & University & 9 & $\mathbf{1 7 0}$ & $\mathbf{1 9 9}$ \\
\hline
\end{tabular}

Source: Field Data (2013)

Table 22 shows that level of education was an important factor on the awareness of the policies governing social schemes. This is evidenced by the fact that the majority of those who were aware of the policies had secondary, college and university education.

In an interview with key informants on the effect of policies, they mentioned that social insurance programmes tend to be gender-blind in that they do not treat women differently from men. They also mentioned that government policies mostly emphasize on compulsory access to some of the existing schemes by those in the formal employment leaving out those in the informal sector. They finally mentioned the long procedures at the time of benefiting from the schemes to be a major hindrance to the access to the schemes.

\section{Desire to join the schemes and Awareness of policies governing Social Security Schemes}

Government policies influence access to social security schemes based on the requirements of the policies. It also influences the awareness of the schemes as it can promote the access to the schemes through creation of awareness among the members of the informal sector on the availability of different social security schemes in the economy. Table 23 below presents the findings of a cross-tabulation of desire to join the social security schemes and awareness of the policies governing the schemes.

Table 23: Desire to join the schemes and Awareness of policies governing Social Security Schemes

\begin{tabular}{|c|c|c|c|c|}
\hline & & \multicolumn{2}{|c|}{ Awareness of policies governing Social Security Schemes } & \multirow[b]{2}{*}{ Total } \\
\hline & & Yes & No & \\
\hline \multirow[t]{2}{*}{ Desire to join the Schemes } & Yes & 17 & 119 & 136 \\
\hline & No & 13 & 51 & 64 \\
\hline Total & & 30 & 170 & 200 \\
\hline
\end{tabular}

Source: Field Data (2013)

Table 23 shows that $17(8.5 \%)$ of those who had the desire to join the schemes were aware of the policies while $13(6.5 \%)$ of those who had the desire to join the schemes were not aware of the policies governing the schemes. This is an indication that awareness of the policies was an important determinant in accessing the social security schemes.

\section{Conclusions And Recommendations}

CONCLUSIONS

From the findings of the study, it can be concluded that gender disparity affected access to the social security schemes. This is evidenced by the fact that in most of the variables under investigation, women were found to be more affected than their male counterparts, thus limiting their access to the schemes the findings revealed that only $13 \%$ who had access to the social security schemes, $(7.5 \%)$ were men while $(5.5 \%)$ were female. It can also be generally concluded that there is low access to the schemes among the members of the informal sector in Laikipia east district. The low number of access is attributed to lack of awareness on the schemes, economic limitations and awareness on the government policies governing access to social security schemes. These conclusions are in line with the findings of a study done by [2] which found that informally employed workers have little or no security of employment or income, and their earnings tend to be very low and to fluctuate more than that of other workers. This is an indication that the low income of those in the informal sector affects their contribution to the schemes. [12] also found that as a result of the economic effects, 
countries have reduced their social spending, which has led to the demise of many of the social protection programs, as well as a reduction in the state's capacity to implement the remaining programs.

\section{RECOMMENDATIONS}

i) This study set out to examine the level of access to the formal social security schemes among members of the informal sector. Based on these findings of the study, it is recommended that those in the informal sector be given special attention with regard to the accessibility to the schemes. This can be achieved by making some aspects of the schemes to be mandatory (like minimum contributions for health schemes, with someexceptions) while others would be voluntary and tailor-made products could be designed and incentives could be introduced to attract informal sector workers, including tax incentives. This would improve the accessibility to the schemes by the members of the informal sector.

ii) This study set out to assess the effect of the level of awareness on access to formal social security schemes among members in the informal sector in Laikipia East District. This study recommended that awareness should be created among the public on the existence of different social security schemes through awareness campaigns. This will increase the level of awareness among the members, a factor that would definitely raise the uptake of such schemes.

iii) This study set out to explore the effect of economic factors on access to formal social security schemes among members in the informal sector in Laikipia East District. This study recommended that the government of Kenya should create more job opportunities especially to those in the informal sector. This will provide this group with some income from which they can make contributions to the schemes. The government of Kenya should also set part of its budget for social security schemes for the members of the public especially for health. This will allow the poor and those who cannot afford the monthly contribution to benefit from the schemes

iv) This study finally set out to explain the effect of government policies on access to formal social security among members in the informal sector in Laikipia East District. This study recommends that there should be a regulatory law in Kenya to establish a regulatory body that is credible, competent and accountable to ensure the smooth, effective and efficient operation of the sector. On the penalties to the defaulters, the government should review the penalties on the defaulters which currently equal to five times the amount of the contribution. This is a major hindrance to those in the informal sector due to their irregular income. For instance, such punitive penalties have hindered NHIF penetration in the informal sector. The government should regulate the amount of monthly remission to the schemes so that the schemes can accommodate even low income earners. The contributions from the members of the informal sector should be lower than those paid by the members of the formal sector. This will encourage membership to the schemes among the members of the informal sector.

\section{References}

[1] Estivill, Jordi, (2003). Concepts and Strategies for Combating Social Exclusion: An overview. Geneva. www.ilo.org/public/english/protection/socsec/step/. Accessed: 13 January 2013

[2] ILO (2000). Income Security and Social Protection in a Changing World. International Federation of Red Cross and Red Crescent Societies: World disasters report: Focus on poverty.

[3] ILO (2003), Extending social security: Policies for Developing Countries. ESS Paper No. 13. (Geneva, International Labour Office, p. 7 .

[4] ILO (2004). "ILO Global Campaign on Social Security Launched in Kenya" available at http://www2.ilo.org/public/english/protection/secsoc/downloads/about/pressrelease_091204.pdf accessed on 4th November 2007.

[5] Lubell, H. (1993). "The Informal Sector in Southeast Asia", in: Work without Protections: Case Studies of the Informal Sector in Developing Countries, US Department of Labor.

[6] Charmes, J. (1998). "Informal Sector, Poverty and Gender: A Review of Empirical Evidence", Paper prepared for PREM, World Bank, as contribution to the WDR 2000.

[7] Garcia, A. \& JB Gruat (2003). Social Protection: A Life Cycle Continuum Investment for Social Justice, Poverty Reduction and Sustainable Development. ILO, Geneva.

[8] Gill, I., T. Packard, and J. Yermo. (2004). Keeping the Promise of Social Security in Latin America. Washington, DC: World Bank.

[9] Mesa-Lago, C. (2008). Social Insurance (Pensions and Health), Labour Markets and Coverage in Latin America, SPD Programme Paper No. 36, UNRISD, Geneva.

[10] Perotti, R. (2003). Political Equilibrium, Income Distribution and Growth. Review of Economic Studies

[11] Hakijamii Trust (2007). The right to Social Security in Kenya-the Gap Between International Human Rights and Domestic Law and Policy, Parallel Report to Committee on Economic, Social and Cultural Rights, Article 9 of the Covenant, November 2007, Nairobi.

[12] Stewart, F. (2006). The Role of Financial Education in Improving Pension Coverage Ratios 